\title{
THE APPRAISAL OF LEGAL FRAMEWORK REGULATING GAS FLARING IN NIGERIA'S UPSTREAM PETROLEUM SECTOR: HOW EFFICIENT?
}

\author{
Olujobi, Olusola Joshua \\ AciArb. \& Notary Public, Legal Practitioner and Lecturer, \\ Business Management Department, Covenant University Nigeria. \\ Olusola-Olujobi, Temilola \\ Legal Practitioner and Senior Partner in Olujobi Olusola \& Co. Lagos, Nigeria.
}

\begin{abstract}
Nigeria is ranked one of the main producers of crude oil in Africa and due to this, oil exploration activities have occasioned high rate of gas flaring which was intensified by poor enforcement of anti-gas flaring laws by the regulatory authorities. Associated natural gas is generated from oil production and it is flared in large volumes, thereby leading to the emission of greenhouse gases and a waste of natural resources which could have potentially spawned billions of dollars for the Federal government. Nigerians are apprehensive that if nothing is done to combat this menace, the environment and man will be at risk due its damaging consequences. There is therefore the need to stop gas flaring by replicating the approaches used in the relatively advanced petroleum countries like Norway to tackle the menace. The research is an appraisal of legal frameworks regulating gas flaring in Nigeria's Upstream Petroleum Sector. It is a doctrinal legal research that adopts a library-based research approach. Weak enforcement and ambiguity of some anti-gas flaring laws are largely identified as the key factors responsible for the menace. It recommends the use of more advanced technologies, sophisticated mixture of regulations and none-regulatory incentives such as fiscal policies, gas market restructuring and proffer practical suggestions.
\end{abstract}

JEL Classifications: K2, K42, Q4, Q5, P28, K32, K12.

Keywords: Depletion, Gas, Gas Flaring, Laws, Ozone Layers, Nigeria 
Cite this Article: Olujobi, Olusola Joshua and Olusola-Olujobi, Temilola, The Appraisal of Legal Framework Regulating Gas Flaring in Nigeria's Upstream Petroleum Sector: How Efficient? International Journal of Advanced Research in Engineering and Technology, 10(3), 2019, pp. 234-250.

http://iaeme.com/Home/issue/IJARET?Volume=10\&Issue=3

\section{INTRODUCTION}

Nigeria is blessed with huge gas reserves of about 159 trillion cubic feet of natural gas and it is ranked one of the top ten countries endowed with natural gas in the world (Orlando, O. 2006). An approximately 2.5 billion cubic feet of gas is asserted being flared by the many oil facilities in Nigeria. Gas flaring is the disposition of natural gas or associated gas that emanates with the crude-oil during oil exploitation and exploration operations.

In the context of this paper, it is an operational waste of energy resources in the petroleum sector that emboldens greenhouse gas emissions. The 1992 United Nations Convention on Climate Change as well as the 1997 Kyoto Protocol requires government to reduce greenhouse gas emissions, but gas flaring also occurs in refineries, oil wells, chemical plants, oil rigs and landfills by fiery off the combustible gas. It also take place, when oil companies burn off the extra gas that escapes due to oil drilling and other oil interrelated activities in the upstream petroleum sector.

Studies have revealed that in relatively advanced petroleum countries like the United States, petroleum companies process natural gas or re-inject the same into the field and only $1 \%$ of the gas is flared but in Nigeria, over $60 \%$ of the associated gas is flared, which could have generated billions of dollars revenues to the Federal government's coffers by processing, distributing, used as cooking gas or to produce electricity for the public to end power outage problem in Nigeria. Nigeria is rated 7th highest gas fiery nation globally by the World Bank's Global Gas Flaring Reduction Partnership (NNPC, 2017).

However, gas flaring being an international concern and major source of air pollution with deleterious effects on climate change have prompted various academic studies which revealed that approximately 150 billion cubic meters or 5.3 trillion cubic feet of natural gas are burnt yearly with 400 million tons of CO2 discharges annually. In Nigeria, an estimated 800 million standard cubic feet (Mmscf) of gas is flared regularly in virtually 144 gas flare locations in Nigeria.

Studies also revealed that oil companies flared an aggregate of 301.69 billion standard cubic feet of gas in November 2016-November 2017 at the exchange rate of $\$ 360$ to a dollar and the Domestic Supply Obligation rate of $\$ 1.50$ per 1,000 Standard Cubic Feet of gas, this means loss of $\$ 162.912$ billion revenues which could have accrued to the Federation account from gas (The Nigeria National Petroleum Corporation Monthly Financial and Operations Report November, 2017).

Besides, the need to combat gas flaring, there is need to safeguard the environment from degradation, to prevent acute damage to the eco-system as well as human health and to generate more revenues to the Federal Government from gas owing to the declined in the global oil price.

Predominantly, gas flaring occurs in the oil producing area of Niger Delta in Nigeria, the government of Nigeria has made numerous attempts to combat gas flaring, but associated gases are still being flared without any efforts to preserve it as most oil companies wrongly assume that they will not have copious financial profits through utilization and commercialization of 
associated gas in Nigeria. Gas flaring is also attributed to non-existence of modern or advanced technologies to utilize and commercialized gas in Nigeria (Okorie, A., 2018).

It is presumed that exploitation of associated gas or re-injection appear to be more costly than flaring and owing to this among others, petroleum companies operating in Nigeria prefer to flare gas because it is cheaper and due to the perceive low investment prospects on associated gas utilization due to absence of sufficient incentives on gas infrastructure and also due to limited markets for gas in Nigeria.

Due to this, appraisals of legal frameworks regulating gas flaring in Nigeria's upstream petroleum sector is sine qua non to combat its deleterious consequences on individuals' wellbeing and on the environment (Otitoloju, A., 2010). The goal of this study is to appraise legal frameworks on gas flaring and make the necessary practical suggestions for reform with a view to exterminating gas flaring in Nigeria.

The paper is divided into five sections, section one comprises of introduction, section two discusses statement of the problems, theoretical framework, international legal framework regulating gas flaring, legal frameworks for combating gas flaring in Nigeria, section three, describes institutional approach to gas flaring in Nigeria. Section five, discusses factors militating against the effectiveness of national legal regimes for combating gas flaring in Nigeria with some lessons Nigerian can learnt other countries blessed with petroleum resources to combat gas flaring, it ended with, conclusion and recommendations.

\section{STATEMENT OF PROBLEMS}

Crude oil being the main source of Nigeria's economy with over $90 \%$ of its foreign exchange earnings amassed from oil and due to the persistent corruption in the sector which have made it intricate for the Federal government to implement its anti-flaring laws strictly to avoid losing multinational oil companies patronage of its oil and to prevent further reduction of oil revenues from the sector which has led to the demand for the diversification of its mono-economy from oil to other agricultural products such as cocoa, groundnut, and palm oil to boost its foreign exchange earnings (Oyewunmi, 2018).

There are also allegations of collusion of multinational oil companies with government officials in the sector to truncate efforts of the Federal government in exterminating gas flaring in the sector in compliance with the International Conventions for Sustainability of the EcoSystem as it is argued that Nigeria flared about $12.5 \%$ of the world's aggregate gas flaring (The World Bank).

However, in Nigeria, series of dates has been set to end gas flaring without any serious commitment to enforce the same. In 1969, the government of General Yakubu Gowon made effort to combat gas flaring in Nigeria by directing oil companies to acquire resources and technologies that will facilitate the use of associated gas in five years but the companies failed to acquire such resources that will gather the flared gas. Similarly, in 1983, another ultimatum date was also fixed as zero flare date with stringent penalties for non-compliance; again in 1984 the date was also changed via executive orders. The date was further shifted to January 1, 2008 as zero tolerance flare period with a serious threat to winding up any oil company that breached the directive however, no oil company has been incriminated or sanctioned after the end of the deadline without any significant compliance with the laws prohibiting gas flaring in Nigeria. Numerous deadlines set by the Federal Government have not deterred gas flaring in Nigeria.

The various academic researchers have shown that some of the hurdles to the Federal government's efforts to end gas flaring in Nigeria are paucity of finance to install essential modern technologies and infrastructure in the sector to prevent gas flaring. Poor enforcement 
of legal, institutional, regulatory framework for combating gas flaring and other environmental risks which was intensified by gas operators limited access to international and local gas markets (Olujobi, 2017).

Also, the Federal government fixed some dates to end gas flaring in Nigeria. Starting from the administration of the former Nigeria Head of State General Yakubu Gowon who fixed 1969 as a date to end gas flaring in Nigeria but the oil companies did not comply with the deadline on the pretext of lack finance to construct gas re-injection plants within the stipulated time. General Muhammadu Buhari also in 1983 resolved to end gas flaring in Nigeria but the date he fixed was not comply with by the oil companies on the excuse of high cost of re-injecting gas. Another date in 1984 was also fixed by the same regime but this was not complied with due to the alleged flaw in the Act which requires license to flare from the Minister for a fee but this excuse is not tenable therefore there is the need for stringent enforcement of Nigeria's antiflaring laws.

In 2003 and 2004 the former president, Chief Olusegun Obasanjo set another deadline to end gas flaring in Nigeria but this was not complied with due to the alleged failure of the government to engage the oil companies before fixing the deadline date. Also, in 2004, the same administration set another deadline to end gas flaring but the oil companies claim that the deadline dates were not expressly spelt out in the legislation. The former president, Umaru Musa Yar'Adua set 2008 and later extended it to 2009 to end gas flaring but these deadlines were not complied with by the oil companies on the ground of alleged failure of the government to engage the oil companies before fixing the deadline dates.

The former president, Goodluck Jonathan set 2011 as another date to end the incessant gas flaring in Nigeria but this date was later extended to 2012, still the oil companies did not comply alleging the same excuses stated above. 2020 is now set as a new date to end gas flaring in Nigeria. Gas flaring will only be a thing of the past through stringent enforcement of Nigeria's anti-flaring laws and regulations with incentives for gas utilization in the sector.

\section{RESEARCH METHODOLOGY}

The objective of this study is to appraise the legal frameworks on gas flaring with a view revealing its efficacies for exterminating gas flaring in Nigeria's upstream petroleum sector with recommended practical measures for ending gas flaring in Nigeria. To achieve this objective, the researchers explore the library-based and doctrinal legal research method, supported by a contextual analysis, including reference to internet sources, an extensive review of academic literature, examination of case studies and the analysis of relevant judicial and statutory provisions. The study adopts secondary sources, such as journals, textbooks and primary sources, such as case laws and statutes and advocates the need to replicate the approaches used in relatively advanced petroleum country such as Norway to tackle the menace.

\subsection{Theoretical Framework for Combating Gas Flaring in Nigeria}

The Sustainable Development Theory of 1980 emanated from Stockholm Conference on Human Environment in 1972 states that government should use their extractive resources in a sustainable way. However, Brundtland Commission Report opined that "Sustainable" is a development that satisfies the current necessities without compromising the ability and the needs of forthcoming generations (Brundtland Report 1987). It is a development where the utilization of extractive resources, the course of financings, thrust of technological advancement and institutional legal framework are in conformity with the international best practices to enhance current and future potentials in the mid-stream sector to satisfy human 
needs with the objectives of encouraging harmony among human beings and between humanity and nature.

The theory emphasizes that the use of natural resources should not jeopardize the value of life of present-day and upcoming generations and should not damage the ecosystems (United Nations Development Programmed, United Nations Department of Economic and Social Affairs and the World Energy Council, 2000). The theory accentuated that man should manage natural resources to aid sustainable development in the sector to combat gas flaring.

Another theory that is germane to this research is the resources curse theory by Richard Auty in 1993 it emphasizes those resources abundant countries are largely suffering from poor economic growths. That resources wealthy countries lack economic prosperity and developments that commensurate with their abundant petroleum resources due to prevalent corruption, failure to diversify their economies and natural resources to other endowments such as agriculture, solid minerals among others to enhance their industrial developments to combat gas flaring and other environmental degradation. There is therefore the need for stringent enforcement of anti-flaring and other environmental laws to protect social, economic and other environment interests in the sector.

\subsection{International Legal Framework Regulating Gas Flaring}

Environmental protection being a major concern to the international community to exterminate the problems connected with climate change owing to the diminution of the ozone layer in the course of gas flaring and other oil exploration activities in the sector.

The declaration of the United Nations Conference on Human Environment Stockholm, 16 June, 1972 on the degradation of the ecosystem by man provide that States are to be cautious to ensure that their undertakings inside their national territories do not trigger harm to the environments of other nations. It affirms further the fundamental right of nations to utilize their extractive resources in conformity with their national environmental legal regimes for the protection of their environments. The Principle 22 of the Declaration, require States to compensate fatalities of effluence and other ecological impairment triggered by their conducts inside their States but enforcement has been the challenge of this international legal instrument.

Also, the United Nations Framework on Climate Change - Kyoto Protocol commenced operation on February 16, 2005, it provides for management, reduction of greenhouse gas emissions to foster clean and healthy human environment. The Federal government appears to lack the political will to end gas flaring by sanctioning oil companies that violates its environmental laws and regulations for combating gas flaring in conformity with the International Environmental Conventions. The Convention has been criticized for its failure to carry African countries along at the time negotiations were ongoing in respect of the Convention.

The Vienna Convention on substances that deplete the ozone layer combats the problems of ozone layer depletion. It imposes responsibilities upon member States to safeguard the ozone stratum in order to safeguard the well-being of man, to preserve the ecosystem from likely harmful effects which are consequences of the activities of man on the environment. Member States are to domesticate the Convention and make their national environmental laws gear towards safeguarding the environment.

Montreal Protocol on substances that diminish the ozone layer combats air pollution at international level. It introduces new techniques for regulatory measures and imposes legal obligations on member-States on restrictions and reduction of the estimated levels of utilization and production of specific regulated ozone diminishing substances. The substances that were 
objects of control are clearly stated in the Protocol, unlike the Vienna Convention which did not expressly spell out all these substances.

The Article 24 of the African Charter on Human and People's Right to Healthy Environment which Nigeria has replicated via African Charter on Human and Peoples Right Ratification Act, Cap. A9 Laws of the Federation of Nigeria, 2004 stipulates the obligations of the member states to provide and guarantee clean and healthy environment.

It is worthy of note that, enforcement of International Conventions on Environmental are weak due to absence of International Environmental court. Some scholars have advocated for its creation and meanwhile submission to the jurisdiction of International Court of Justice is voluntary, Member States cannot be compelled to submit to the authority of the International Court of Justice to ventilate its environmental degradation grievances.

On the other hand, environmental degradation has trans-boundary deleterious effects on nations which prompted nations to adopt environmental friendly policies and regulations and to exhibit international cooperation to combat the menace of gas flaring but sometimes some members States fail to comply with these International Environmental Protection Conventions due to absence of stringent sanctions for non-compliance with its provisions and this has increased environmental abuses and degradation in the oil sector (Olujobi et al, 2018).

\subsection{National Legal Regimes for Combating Gas Flaring in Nigeria}

In Nigeria, several legislative efforts have been made to combat gas flaring particularly sections 33(1) and 34(1) of the 1999 Constitution that guarantees right to life and right to dignity of human person. These rights can only be sustained through clean and healthy environment, but Section 3(2)(a)(b) of the Associated Gas Rejection Act which allows gas to be flared with the consent of the Minister of Petroleum is in contravention of the 1999 Constitution that guarantees right to life and right to dignity of human person, therefore the Act became null and void in line with section 1(3) of the 1999 Constitution (as amended).

Furthermore, Sections 13 and 20 of Chapter two of the same 1999 Constitution (as amended) fail to make breach of the duty of the Federal government to protect Nigeria's environment from environmental degradations enforceable. The Constitution fails to provide direct legal remedies for environmental degradation. The Associated Gas Re-Injection Act was legislated to prohibit gas flaring on January 1, 1984, the date was later changed to December 2003 and it was subsequently moved to 2006, it was also shifted from January 2008 to December 2008.

In July 2, 2009, the National Assembly enacted the Gas Flaring (Prohibition and Punishment) Act, 2009 with a gas flaring time limit fixed for December 31, 2010. The deserted Petroleum Industry Bill also set gas flaring deadline for 2012. The Gas Flaring Prohibition and Punishment Bill, 2016 set the ultimatum for gas flaring to December, 2016. Several deadlines with paltry sanctions were fixed by the Federal Government which has not deterred gas flaring in Nigeria.

The Gas Flaring Prohibition and Punishment Bill and Associated Gas Re-Injection (Amendment) Bill are still pending before the National Assembly with the aims of combating the challenge of gas flaring in Nigeria and minimizing ecological consequences of gas flaring.

In addition, the Flare Gas (Prevention of Waste and Pollution) Regulations, 2018 is to combat Green House Gas emissions via flaring and venting of natural gas in Nigeria. It adopts the polluter pays principle with carbon tax (Nnona, G., 2003). It is to increase the penalty from N10 per thousand Standard Cubic Feet for gas flaring especially where the companies produced more than 10,000 barrels of oil or more to \$2.0 USD per thousand Standard Cubic Feet of Gas 
and where the company produced less than 10,000 barrels of oil per day \$0.50USD per thousand Standard Cubic Square Feet of Gas. Its sanctioned failure not to make available precise flare figures and denial to offer access to flare sites with suspension or termination of operating license. It offers to implement the provisions of the Nigerian Gas Flare Commercialization Programmed but it has not changed the legal landscape in Nigeria by combating gas flaring due to poor enforcement and non-monitoring of the activities and operations of these petroleum companies with the applicable extant anti-gas flaring and other environmental laws in Nigeria (Olujobi, 2017).

In an attempt to combat gas flaring and to transform flared gas to commercial benefits, the Federal Government initiated the Nigerian Gas Flare Commercialization Programmed (NGFCP) to transform the mid-stream sector, this will only achieve its objective if implemented stringently and consistently to combat gas flaring.

It is imperative also, to note that Section 44 (3) of the 1999 Constitution of the Federal Republic of Nigeria (as amended) and Section 1(1) of the Petroleum Act 1969 (as amended), confers title to petroleum and other extractive resources on the Federal Government but this does not impede the right to compensation from damage suffered or that occurred from petroleum exploration, production activities and gas flaring. Elf Nigeria Limited. Opere Sillo and Anor (1994) 6 NWLR [Pt.350] 258 and Shell Petroleum Development Company Ltd. Councillor F.B. Farah and Others [1995] 3 NWLR [Pt. 382] 148 at 185.

As part of the efforts of the Federal Government to combat gas flaring, the Department of Petroleum Resources is statutorily entrusted to manage the oil sector as well as the NNPC through its subsidiary, the Nigeria Gas Company which is assigned to regulate gas transmission and distribution in Nigeria with a monopoly of gas pipelines in Nigeria. This is a concern for potential investors. There is therefore the need for explicit statutory guidelines on the roles of the agency and for adequate gas pipelines for efficient utilization of Nigeria's vast gas resources to boost the Federal Government's foreign exchange earnings and to mitigate business risks in the sector.

In addition to all other efforts in the sector, the Federal Government set April - October 1980 for oil companies operating in Nigeria to remodel gas application projects and to combat gas flaring. In 1984, a fine was introduced into the Associated Gas Re-Injection (Continued Flaring of Gas) Regulations which gave room for limited indemnities to flare gas in certain circumstances. This was also amended 1985 with a fine of 2 Kobo for non-compliance for each 1000 standard cubic feet of gas flared. The fine appears too inadequate and the Federal Government increased the fine in January, 1998 to US\$11 for every 1000 standard cubic feet of gas flared.

The Associated Gas Re-Injection (Amendment) Act, 2004 was also enacted. It required detailed plans for gas utilization with zero tolerance for gas flaring by oil and gas companies unless exemption is given by the Petroleum Minister. The sanctions prescribed by the Associated Gas Re-injection Act against petroleum companies for flaring gas are inadequate, due to that, the Act has not achieved its aims. The decision of the Tax Appeal Tribunal in the case of Mobil Producing Unlimited v. Federal Inland Revenues Services [2017] All FWLR 543 which prescribed punishments for gas flaring as enshrined in the Associated Gas Reinjection Act are tax deductible. This implies that oil companies can flare gas as much as they desire as the prescribed penalties are deemed subtracted from their taxable incomes. This unsatisfactory verdict appears to have aggravated gas flaring by oil companies in the sector.

The National Policy on the Environment and Nigeria's National Agenda 21, originated by the Federal Ministry of Environment for proficient directives on air quality, standard and natural gas preservation with the aim of combating gas flaring and other environmental risks 
in the sector. Also, the Policy for Natural Gas Conservation and Development which require that Production Sharing Contracts executed by oil companies must embrace gas application clauses to combat gas flaring and to guarantee healthy and sustainable environment. Gas companies are obliged to perform gas field optimization reports on their gas concessions to prevent gas flaring. Non-compliance with this policy has not attracted any severe sanction as several oil companies have not performed their gas field optimization and none have been sanctioned stringently in the sector.

The Gas Flaring (Prohibition) Bill, 2017, the Bill is currently undergoing legislative scrutiny at the National Assembly. There is therefore the need for thorough review of the notable gaps in the bill especially the provisions on taxes and other fiscal policies to avoid double taxations and other legislative lacunas before it finally crystallised into law for combating gas flaring. Also, the Downstream Gas Act is to combat governing and institutional policies restrictions on investments in the downstream petroleum sector which may impede potential investors especially where the government appears not to have the political will to enforce its anti-flaring laws.

The National Environmental Standard Regulation Enforcement Agency (Establishment) Act (NESREA) 2007 expressly annulled the Federal Environmental Protection Agency Act (FEPA), 1988. The aim of NESREA is to protect and develop Nigerian environment, biodiversity protection and to ensure sustainability of its extractive resources. See Sections 7(g), (h), (j), (k), (i) and 8(g), (k), (l), (m), (n)(s) of the Act. It set up mobile courts for speedy trial of those that violate its provisions but the Act expressly prohibits petroleum industry from its operations. The penalties for violations of its provisions are penal in nature without any provisions for civil remedies for victims of environmental infringements; this is another flaw of the Act.

It is pertinent to note that, oil companies are excluded from environmental audit and from establishing repository on governing and implementation of mechanisms on environmental standards. The agency's power of investigations of oil pollution is limited to oil spillage as stated under section $8(\mathrm{~g})$ of the Act which another flaw of the Act. The exclusion of oil and gas companies' environmental degradation and pollution from the scope of the agency appear to be a serious legislative setback in combating gas faring in Nigeria's mid-stream sector.

The Act combats gas flaring by oil companies being a legal entity and by its employees who are individually prone to incarceration for a term not above 10 years respectively. Section 20(4)(5) of the Act allows the Minister to combat gas flaring and in certain situations, the Minister may award special license to flare for a short period and failure to conform attracts punishment not above $\$ 500,000,000.00$. These sanctions appear to be inadequate considering billions of dollars being generated by the petroleum companies operating in the sector.

Section 27(2) of the Act, prohibits the release of deleterious substances into the air, land and water in Nigeria with a fine not above $\$ 100,000$ or one year incarceration, if committed by a legal entity on conviction a fine not above $\$ 100,000$ and supplementary fine of $\$ 50,000$ for each day that the infringement continues may be imposed. These penalties appear too meager to combat environmental degradations in the sector. Restoration should be added to the remedies for environmental degradation to discourage environmental abuses and gas flaring by oil companies.

The Petroleum Drilling and Production Regulation Act, 1969 was enacted in conformity with the Petroleum Act to oversee the petroleum exploration and production in Nigeria. The Regulation 42 requires that oil companies are to submit scheme for application of natural and associated gas discovered in the course of oil exploration. Oil companies are to make use of advanced technologies or equipment but most of the equipment being utilized by these oil 
companies are obsolete and in bad shape thereby making enforcement of this Act impracticable. Another flaw of the Act is the failure to define "Good oil field practice" or set the yardstick for estimating oil field. The oil companies in Nigeria has not complied with the Act, neither has the Act been implemented by the regulatory agencies in the sector against oil companies for gas flaring. (Jamilu Ibn, M., 2016).

The Harmful Waste (Special Criminal Provisions Act Vol. 7, Cap H1, LFN 2004), Section 6 prohibits acquisition, trade deposit and stowage of toxic waste with penalty of life imprisonment if found culpable of the offence and where the offence was committed by legal entity, the officer of the company shall be liable except if the offence was committed without his knowledge. The major weakness of the Act is the failure to extend the Act to all forms of harmful wastes including gas flaring in the sector.

The multinational oil and gas companies have not also complied with the above provisions and it has also not been strictly enforced by the regulatory authorities in the sector due to absence of stringent sanctions under the regulation for non-compliance with its provisions. The laws appear not to be in conformity with the current legal reality in the gas sector and the anticipated challenges. Therefore, there is the need for reform in conformity with the presentday developments in the international mid-stream sector. The reform must inculcate zero tolerance for gas flaring, environmental protection and active corporate social responsibility by oil and gas companies to promote sustainable development in the sector.

The Petroleum Industry Governance Bill, 2017 which replaced the Petroleum Industry Bill, 2012. This Bill prohibits gas flaring without approval from the Minister with a penalty not less than the worth of the gas flared but the Bill has not been assented to by the President to commence operation in the sector.

The Flaring (Prohibition and Punishment) Bill, 2010 prescribed stiffer penalty including closing down of oil fields that failed to comply with its provisions. The Environmental Management Bill, 2010 made the Directors of oil companies liable for gas flaring with ten years' incarceration or fine of $\$ 500$ Million on conviction but this Bill has not been passed into law.

To combat gas flaring, the Federal Government also endorsed the Paris Climate Change Agreement and signed the Global Gas Flaring Partnership's principles to end global flare in 2030. Nigeria is committed to end a national gas flaring in 2020. The Federal Government is empowered by virtue of Paragraph 35b of the First Schedule of the Petroleum Act, 1969 (as amended) to capture gas at flame. This prompted the introduction of Nigerian Gas Flare Commercialization Programmed in 2016 (as earlier said) to promote technical and commercial sustainability of gas utilization in Nigeria through third party investors to combat gas flaring and to enhance market driven by commercial structure which will enables flared gas to be merchantable in Nigeria and in other developed gas market.

The various national legal frameworks enacted to combat gas flaring and to promote sustainable development and utilization of gas have not been efficiently implemented, enforced, monitored and evaluated by the various regulatory agencies saddled with the task, due to lack of political will and commitment to enforce the extant anti-flaring and environmental laws to combat continuous flaring of gas by oil companies in Nigeria.

\subsection{Institutional Approach to Gas Flaring in Nigeria}

The institutions saddled with the responsibilities of regulating gas flaring are among others: The Ministry of Petroleum Resources and Energy, the ministry is headed by a Minister who is statutory empowered to formulate policies regulating the oil industry via the Department of Petroleum Resources (DPR) to enact regulations for oil exploration and production in Nigeria. 
To reduce gas flaring, DPR must perform efficiently its statutory function of regulating the oil sector devoid of corruption and breach of the extant environmental laws.

The Nigeria Gas Company (NGC) regulates the mid-stream sector to commercialize gas through the development of fully integrated gas supply system. It has not lived up to expectation as it has not fully optimized economic potentials of Nigerian gas for the economic benefits of Nigerians and potential foreign investors (Ofurhie, M. 2006) to end gas flaring and other environmental hazards in the sector there is need for urgent reform of the institution.

The Nigerian National Petroleum Corporation, exercises both fiscal and regulatory functions in the sector, it has twelve subsidiaries, encompassing the whole gamut of oil industry operations. The corporation should be allowed to compete commercially with other oil companies in the sector via its upstream subsidiary Nigeria Petroleum Development Company. NNPC should be given full autonomy devoid of governmental interference to enhance its full operation capacities like other legal entities operating in the sector. The Federal Ministry of Environment was also set up in 1992 to regulate the environment and to prevent environmental hazards in Nigeria especially in the petroleum sector.

The Niger Delta Development Commission NDDC was also created by the Niger-Delta Development Commission Act, 2000 due to the Federal Government's desire to end ecological problems in the oil churn out communities and to combat environmental and ecological problems associated with the petroleum sector's operations as stated under Section 3, 7 of the Act.

The major challenge of the agency is mismanagement, corruption and poor funding due to failure of some oil companies to comply with Section 14(3) (b) of the Act which require payment of $3 \%$ of oil companies' budgets to the agency and persistent refusal of the Federal government to fulfill its legal commitment of $15 \%$ subvention annually to the agency (Abila S.E and Damfebo K.D., 2006). The activities of the regulatory authorities in the sector over the years on gas flaring appear to be uncoordinated and not proactive enough to combat the menace in the sector.

\subsection{Factors Militating Against the Effectiveness of National Legal Frameworks for Combating Gas Flaring in Nigeria}

The above stated statutes protect the environment from the deleterious effects of human activities and the challenge has been poor enforcement, monitoring and lack of political will to implement the laws and not inadequacies of the laws. There is poor enforcement, implementation and monitoring of the existing anti-flaring and environmental laws by the various regulatory agencies in the sector. This is having limited the efficacies of the anti-gas flaring and other environmental laws in the sector. Other limitations that hamper efficiency of the laws are:

The absence of gas flares management legal framework and absence of more advanced technologies to capture flared gas for electricity generation to eliminate gas flaring in the sector. There is also the absence of efficient regulatory, legal framework with techniques for computing, monitoring, appraising, enforcing anti-flaring provisions with compulsory installation of advanced modern operational equipment for eliminating gas flaring in Nigeria.

Also, the regulatory and legal regime for combating gas flaring must be explicit and definite but there is absence of clear and explicit legal regime for combating gas flaring in Nigeria. The various fines or penalties embedded in the anti-flaring and other environmental legislations are meager to an extent that some oil companies prefer to flare gas and become liable for environmental offences and to pay the sanction due to paltry monetary values attached as fine. 
Another challenge is inexperienced staff, insufficient facilities or equipment by the regulatory authorities in the sector to measure quantity of gas flared and to ascertain the degree of damage done by gas flared or other environmental hazards thereby occasioned absence of comprehensive and accurate ecological data in the sector. It is also observed that corruption and bribery among the various environmental officials and regulatory agencies in the sector hampered efficiencies of the laws in combating gas faring in Nigeria.

There is also weak judiciary, over congested court cases which have hampered efficient enforcement of Nigeria's anti-flaring and environmental laws due to incessant adjournments of environmental cases, delays in the prosecution and trials of environmental cases and the alleged existence of corruption among Nigerian judges.

The Federal Government and its regulatory agencies lack the political will to implement the various environmental legal regimes to combat gas flaring and other environmental degradations in the sector and the existence of multiple statutory defenses opened to oil companies and individuals when charged or accused of environmental violations. The potency of these defenses has given the accused oil companies opportunities to escape punishments and this should be reviewed through case laws and statutory guidelines to combat the menace.

Another impediment, is inelegant skills and techniques for prosecuting environmental crimes in Nigeria as environmental offences are prosecuted by the Ministry of Justice with nonchallant attitude, unlike other petroleum endowed country like Norway where environmental crimes are prosecuted professionally in conformity with their national legal frameworks with stringent sanctions imposed for non-compliance by individuals and corporate legal entities in the sector and in accordance with their obligations under International Conventions for eradicating gas flaring.

\section{DISCUSSION OF FINDINGS}

The writers observe non-existence of gas flare management legal framework and absence of advanced technologies to capture flared gas for electricity generation and to eliminate gas flaring in the sector. There is also absence of efficient regulatory legal framework with techniques for computing, monitoring, appraising and enforcing anti-flaring law's provisions with compulsory installation of advanced modern operational equipment for eliminating gas flaring in Nigeria's oil companies.

It is the view of the writers that, for there to be an effective regulation of gas flaring, the Act must be comprehensive and provide for computation and reportage of volumes of gas flared and vented, which would in turn provide for precise data about gas flaring and venting volumes to the regulatory authorities for combating the menace in the sector. The research found out that gas flaring rate is still at the highest level despite existence of numerous antiflaring laws.

The limitations of the study is the absence of accurate data on the quantity of gas churned out and the volume of gas flared in the oil fields by oil companies in Nigeria this would have enhanced insight to the levels of gas flared and vented in the sector and enhanced the panacea for combating gas flaring.

Strict regulatory measures should be put in place for oil companies to compulsory submit their environmental impact assessments on expected emissions and discharges from gas flaring and to state detailed measures put in place for mitigating its environmental impacts in the sector. 


\subsection{Lessons Nigeria Can Learn from Norway}

The laws regulating petroleum activities and the contractual agreements between the Federal Government and the oil companies should be detailed on the management and elimination of gas flaring as it is practiced in Norway. Licenses to be issued to new oil company and license renewals, production sharing arrangements and joint venture agreements should contain clauses on gas utilization projects and elimination of gas flaring with stringent penalties such as revocation and payment of pecuniary damages for non-compliance as it is practiced in Norway.

The legal regimes for combating gas flaring must not be ambiguous and it must entail proactive monitoring, reporting and enforcement mechanisms. Fixing dead line to end gas flaring must be done consensus ad idem by all stakeholders in the sector for feasible date to exterminate gas flaring with stringent penalties for non-compliance as agreed by the parties. To combat gas flaring like Norway, there is therefore the need to benchmark oil production with the capacity of gas utilization by oil companies operating in Nigeria before the Department of Petroleum Resources can issue the relevant operating oil license to oil companies in order to end gas flaring menace in the sector.

\subsection{Recommendations}

National Environmental Standard Regulation Enforcement Agency (Establishment) Act (NESREA), 2007 should be amended to extend its purview to oil and gas sector pollution and other environmental degredations to combat gas flaring in the sector. Section 20 of the 1999 Constitution (as amended) on enforcement of environmental objective should be overhauled and moved to the Fundamental Human Rights in chapter four of the 1999 Constitution, thereby making it justiciable to all, it will thus protect, gurantee healthy and sustainable environment and it will prevent gas flaring by oil companies through payment of pecuniary damages to the Federal government and the victims of environmental degredations to promote stringent compliance with the anti-flaring policies and other environment laws in the sector.

There is therefore the need for detailed, fiscal, legal and regulatory framework governing gas utilization and development that will unbundling the gas pipelines networks with effective gas distribution zones in Nigeria. There is also the need for a review of regulatory framework with satifactory operational mechanism to ensure proper implementation of the anti-flaring laws and other regultaory policies. Nigeria is referred to as gas province because of the tremendous economic benefits the sector will offer the nation due to this, there is the need to avoid overlapping of functions among the various regulatory institutions for efficiency in the performance of their statutory roles in the sector to enhance gas distribution networks and to prevent gas flaring.

Poor enforcement of anti-flaring laws due to low human capacity and poor funding, there is therefore the need for more private sector participation in gas distribution networks to ensure gas availability, development, increase gas utilization, increase its economic storage to reduce gas flaring.

There is also the need for oil companies to update their drilling tools in conformity with international standards to end gas flaring through modern technologies; this is to guarantee environmental protection and natural resources management. Regulatory policies should be transparent with incentives for gas development and utilization. Again, there is the need for oil companies to implement Environmental Management System that will determine possible environmental impacts of its activities and to put in place appropriate measures to combat same in the sector. 
The Federal government should increase electricity generation in Nigeria through the use of gas. There is the need for installation of gas flare meters electronically with data recovery mechanisms, independent reportage and scrutiny by the Nigerian Gas Company. There is therefore the need for stringent financial sanctions for non-compliance with anti-flaring laws. The study advocates the need to use the flared gas for electricity generation in Nigeria to earn more revenues to the Federal Government through local utilization and exportation of gas.

There is the need for more gas pipeline network to enhance domestic usage of gas and to reduce its flaring. Gas prices should be reasonable and competitive with other forms of energy dictated by the market forces to encourage investors to invest in the sector and to deter waste of resources and to decline environmental risks. There is the need for explicit master plan for the construction, networking of a national gas transmission and distribution network since this is sine qua non for national gas development, monitoring and sustainability in the sector.

\section{CONCLUSION AND POLICY IMPLICATIONS}

The research has examined the various legal frameworks for combating gas flaring in Nigeria. The research has evaluated several efforts made by the Federal government to combat gas flaring in Nigeria and this has offered ways of exploiting the gas flared to actualize the zerogas flaring country in 2020. The flaws of the various laws examined were brought to the fore. Suggestions were made, where suitable, in addressing the flaws. Regulatory authorities are to come up with practical and reasonable ways of monitoring compliance in relations to the volume of gas flared or vented, vis-à-vis the permissible levels. Nigeria should put in place a gas utilization policy that clearly indicate the role of oil companies in flare and vent reductions.

Strict implementation, monitoring and enforcement of the Nigeria Gas Flare Commercialization Programmed will save for the Federal Government huge revenues lost to gas flaring which could have been utilized for infrastructure development and enhance power supply in the country. Strict implementation of environmental protection laws to enhance ecological development and financially viability of oil producing communities in Nigeria to combat unfriendly practices in the sector through stringent implementation of strategic environmental protection measures that will combat gas flaring in the sector.

There is the need for national gas transmission grid for easy access by potential users in Nigeria to enhance gas utilization and development through private sector participation projects with detailed, coherent and practicable gas policy for the nation to encourage gas investors and to end the reliance on impromptu policy statements by public officials as guidelines in the sector.

Prescriptive approaches can also be adopted to end gas flaring, where oil and gas companies are obliged to comply with the specific and detailed gas flaring regulations established by the regulatory authorities with stringent enforcement procedures and sanctions for non-compliance with the appropriate incentives for compliance with gas flaring laws.

Practically, imposing detailed technical regulations on oil companies to eliminate flaring may be a herculean task. Measuring gas flared volumes and analyzing compliance in each oil production location may be unrealistic and may be expensive.

To make the regulation efficient, the regulatory authorities must enforce anti-flaring laws without fear or favour to ensure total compliance with the anti-flaring and other environmental laws to combat gas flaring in Nigeria's mid-stream sector. Optimal development of gas reserves with more advanced technologies will add enormous economic benefits to Nigeria and Africa continent if properly executed by the regulatory authorities in the sector as the legal and regulatory regimes for combating gas flaring and other environmental degradation in the oil 
and gas sector are poorly implemented and monitored by the regulatory agencies saddled with the responsibilities of enforcing the laws.

\section{ACKNOWLEDGMENT}

The financial support by Covenant University, Ota, Nigeria is gratefully acknowledged.

\section{DISCLOSURE STATEMENT}

The authors declare no conflict of interest whatsoever.

\section{REFERENCES}

[1] Agboola et al., (2011), International Journal of Thermal and Environmental Engineering, 2, p.73.

[2] Jamilu Ibn, M., (2016) “Comparing Nigeria's Legal Framework for Combating Gas Flaring with That of Norway - Lessons for Nigeria" Imperial Journal of Interdisciplinary Research (IJIR) Vol-2, Issue-9, p.1253.

[3] Malumfashi, G.I., (2007) "Phase-Out of Gas Flaring in Nigeria by 2008: The Prospects of a Multi-Win Project Review of the Regulatory, Environmental and Socio-Economic Issues, Nigeria Gas Flaring Petroleum Training Journal, Vol. 4, No. 2, pp.1-39.

[4] Nnona, G., (2003), "New Policy Regime for Gas in Nigeria a Perspective on Tax and Related Incentives", Journal of Energy and Natural Resources Law, pp. 285-302

[5] Obayomi A., (2009), International Environment Regimes of Gas Flaring, LLM Seminar paper, Energy Resources Class, Jurisprudence and International Law Department, University of Lagos.

[6] Okafor, J.C., (2016), Nigeria and World Bank Global Gas Flaring Reduction Partnership: The Tragedy of the Commons Developing Country Studies Vol.6, No.12.

[7] Oke, Y. (2012), Beyond Power Sector Reforms: The Need for Decentralized Energy Options (DEOPs) for Electricity Governance in Nigeria, Nigerian Journal of Contemporary Law, UNILAG, p.67.

[8] Okorie A., (2018), "The Dominance of Foreign Capital and its Impact on Indigenous Technology Development in the Production of Liquefied Natural gas in Nigeria", Review of African Political Economy, pp.478-490.

[9] Olujobi, O.J. (2017), Legal Framework for Combating Corruption in Nigeria - The Upstream Petroleum Sector in Perspective, Journal of Advanced Research in Law and Economics, Vol. VIII, Summer, 3(25): 956.

[10] Olusola J. Olujobi, Olabode A. Oyewunmi, Adebukola E. Oyewunmi (2018), Oil Spillage in Nigeria's Upstream Petroleum Sector: Beyond the Legal Frameworks, International Journal of Energy Economics and Policy, 8(1), 220.

[11] Odianonsen Francis IYOHA and Olusola Joshua OLUJOBI et al (2017) "Application of the Laws of Defamation and Sedition in Nigeria's Jurisprudence: Still Relevant?" Journal of Advanced Research in Law and Economics, Volume VIII, Spring, 1(23): 59 - 68.

[12] Olujobi, Olusola Joshua and Olusola-Olujobi, Temilola, (2019) "Insolvency Law and Business Recovery Practices in Nigeria's Upstream Petroleum Sector: The Need for a Paradigm Shift", International Journal of Mechanical Engineering and Technology 10(1), 2019, pp. 1609-1628.

[13] Anthonia Adeniji; Adewale OSIBANJO; Odunayo SALAU; Olusola OLUJOBI; Hezekiah FALOLA; Maxwell OLOKUNDUN and Chimazuru, AKANWA, Alternative Dispute Resolution and Commitment of Staff of Selected Construction Companies, International Journal of Civil Engineering and Technology, 10(2), 2019, pp. 1071-1081. 
The Appraisal of Legal Framework Regulating Gas Flaring in Nigeria's Upstream Petroleum Sector: How Efficient?

[14] Olusola Joshua Olujobi, Olabode Adeleke Oyewunmi (2017) Annulment of Oil Licences in Nigeria's Upstream Petroleum Sector: A Legal Critique of the Costs and Benefits International Journal of Energy Economics and Policy, 7(3), 364.

[15] Omorogbe, Y.Oil and Gas Law in Nigeria, Malthouse Press Ltd., 2001.

[16] Otitoloju, A., (2010) "Effects of gas flaring on blood parameters and respiratory system of laboratory mice, Mus musculus" Environment Systems and Decisions December 2010, Volume 30, Issue 4, pp 340-346

[17] Oyewunmi and Olujobi (2015) Transparency in Nigeria's Oil and Gas Industry: Is Policy Re-engineering the Way Out? International Journal of Energy Economics and Policy Vol.5, Iss. 4 p.631.

[18] Oyewunmi, (2018) Oil Price Fluctuations and Dependency Malaise: What will Engender Socio-economic Adjustments? International Journal of Energy Economics and Policy Vol. 8 Iss.6, pp.167-173.

[19] Oyewunmi, O. A., and. Oyewunmi.A.E., (2016) "Managing Gas Flaring and Allied Issues in the Oil and Gas Industry: Reflections on Nigeria", Mediterranean Journal of Social Sciences, p.643.

[20] Abila S.E and Damfebo K.D Sustainable Development Issues in the Niger Delta Emiri, F., and Deinduomom, G., (ed), Law and Petroleum Industry in Nigeria Current Challenges Essay in Honour of Justice Kate Abiri (Malthouse Law Books, Lagos, 2009), p.268.

[21] Amokaye O. G; Environmental Law and Practice in Nigeria (University of Lagos Press, 2004.), p.6.

[22] Damfebo, K.D, Sylvanus, E.A, A Critical Examination of the National Environmental Standards and Regulations Enforcement Agency (Establishment) Act, 2007 Emiri, F., and Deinduomom, G., (ed), Law and Petroleum Industry in Nigeria Current Challenges Essay in Honour of Justice Kate Abiri (Malthouse Law Books, Lagos, 2009), p.2.

[23] Ofuhie, M., Investment Potentials in the Nigerian Gas Sub-Sector, Chartered Institute of Bankers of Nigeria, (2006) Oil and Gas Financing in Nigeria Issues, Challenges and Prospects, (The Chartered Institute of Bankers of Nigeria, Lagos 2006), p.120.

[24] Orlando, O., Construction and Networking of Gas Distribution Infrastructure, Chartered Institute of Bankers of Nigeria, (2006) Oil and Gas Financing in Nigeria Issues, Challenges and Prospects, (The Chartered Institute of Bankers of Nigeria, Lagos 2006), p.243.

[25] Lawrence Atsegbua et al; Environmental Law in Nigeria, Theory and Practice, Ababa Press Ltd., 2004.

[26] Elf Nigeria Limited v. Opere Sillo and Anor (1994) 6 NWLR [Pt.350] 258

[27] Mobil Producing Unlimited v. Federal Inland Revenue Services (2015) TAT/LZ/033/2013.

[28] Shell Petroleum Development Company Ltd V. Councillor F.B. Farah and Others [1995] 3 N.W.L.R (Pt. 382) 148 at 185.

[29] Associated Gas Re-Injection Act, Cap 26, Laws of the Federation (LFN), 1990.

[30] Nigeria LNG (Fiscal Incentives Guarantees and Assurance) Act, No. 39, 1990.

[31] Environmental Guidelines and Standards for the Petroleum Industry in Nigeria 2002.

[32] Abisoye , K., (2017) DPR Engagement with Companies on Data Requirements for the Nigerian Gas Flare Commercialization Programme (NGFCP), available at: https://www.dpr.gov.ng/dpr-engagement-with-companies-on-data-requirements-for-thenigerian-gas-flare-commercialization-programme-ngfcp/ (visited November 20, 2018).

[33] Abuhesa, M.B., (2010) Investigation into Gas Flaring Reduction in the Oil and Gas being a Ph.D Thesis Submitted to the Salford University, available at: Industryhttp://usir.salford.ac.uk/30794/1/PhD10.pdf (visited December 6, 2018). 
[34] Win-Win

Situation?

Available

at

http://www.mondaq.com/Nigeria/x/689396/Oil+Gas+Electricity/The+Nigerian+Gas+Flar e+Commercialization+Programme+A+WinWin+Situation (visited November 20, 2018).

[35] Department of Business, Energy and Industrial Strategies, (2018), Digest of United Kingdom Energy Statistics 2018, available at: https:/assets.publishing.service.gov.uk/government/uploads/system/uploads/attachment_ data/file/728438/DUKES_LTT.pdf(visited December 18, 2018),p. Annex E.

[36] Dodondawa, O., (2018) "NGFCP: The Government Intervention that May End Routine Gas Flaring by 2020" Available at: https://www.tribuneonlineng.com/157616/ (visited November 20, 2018).

[37] Foreign Affairs, Trade and Development Canada, (2015) "Invest in Canada" Available at:https://www.international.gc.ca/investorsinvestisseurs/assets/pdfs/download/oil_and_g as.pdf (visited December 16, 2018), p.3.

[38] Ishaya. A., (2018) “The Nigerian Gas Flare Commercialization Programme: A Win-Win Jamie Stewart, R. (2014) A Review of Flaring and Venting at UK Offshore Oilfields An analogue for offshore Carbon Dioxide Enhanced Oil Recovery Projects? Available at: http://www.sccs.org.uk/images/expertise/reports/co2-eor-jip/SCCS-CO2-EOR-JIP-

WP11-Flaring-Venting.pdf (visited December 6, 2018), p.5.

[39] Kachikwu, I., What Gas Flaring Prohibition bill will Achieve, available at: https://punchng.com/gas-flaring-prohibition-bill-will-achieve/ (visited November 20, 2018).

[40] Manning and Tamura-O' Connor, B., Oil and gas regulation in Canada: Overview, available at:https://uk.practicallaw.thomsonreuters.com/3-633 1728 ?transitionType $=$ Default $\&$ contextData $=($ sc. Default $) \&$ firstPage $=$ true $\&$ comp $=$ pluk $\& b$ hcp=1 (visited December 17, 2018).

[41] National Energy Board, (2017) Canada's Energy Future 2017 Supplement: Natural Gas Production, available at: https://www.neb-one.gc.ca/nrg/ntgrtd/ftr/2017ntrlgs/indexeng.html?=undefined\&wbdisable=true (visited December 18, 2018).

[42] NNPC (2017), NNPC: Nigeria Drops to Seventh Highest Gas Flaring Country, available at: https://www.thisdaylive.com/index.php/2017/04/03/nnpc-nigeria-drops-to-seventhhighest-gas-flaring-country/ (visited November 20, 2018).

[43] Ojijiagwo, E.N., (2017) "Development of a Sustainable Framework to Manage Flare Gas in an Oil and Gas Environment: A Case Study of Nigeria" Available at: https://wlv.openrepository.com/bitstream/handle/2436/620607/Ojijiagwo\%20\%20PhD\%2 0Thesis.pdf?sequence=1\&isAllowed=y (visited December 18, 2018), p.61.

[44] Situation?" Mondaq Business Briefing, April 5, 2018 Issue. Available at:http:/www.aelex.com/wp-content/uploads/2018/03/the-nigerian-gas-flarecommercialization-programme.pdf (visited December 20, 2018).

[45] Ugochukwu, C.N.C., (2008), Sustainable Environmental Management in the Niger Delta Region of Nigeria: Effects of Hydrocarbon Pollution on Local Economy, available at: https://opus4.kobv.de/opus4-btu/files/438/Collins_Ugochukwu_PhD_Dissertation.pdf (visited December 6, 2018), p.187.

[46] United Nations Development Programme, United Nations Department of Economic and Social Affairs and the World Energy Council, "World Energy Assessment: Energy and the Challenge of Sustainability" UN 2000, available at: http: www.undp.org/content/dam/undp/library/Environment \%20and \%20Energy/Sustainable\%20Energy/wea\%202000/Overview.pdf (visited November 22, 2018) 
The Appraisal of Legal Framework Regulating Gas Flaring in Nigeria's Upstream Petroleum Sector: How Efficient?

[47] World Bank, 2006. UK Flaring Policy, available at: http://siteresources.worldbank.org/EXTGGFR/Resources/5780681258067586081/UK_Fl arigPolicy.pdf (visited December 6, 2018).

[48] Nigeria National Petroleum Company, (2018) Development of Nigeria's Oil Industry, available

at: http:/nnpcgroup.com/NNPCBusiness/BusinessInformation/OilGasinNigeria/Developmen toftheIndustry.asp (visited December 30, 2018)

[49] Report of the World Commission on Environment and Development (The Brundtland Report), Our Common Future 43 (1987) Oxford University Press. 